\title{
Patterns of extinction risk and threat for marine vertebrates and habitat-forming species in the Tropical Eastern Pacific
}

\author{
B. A. Polidoro ${ }^{1, *}$, T. Brooks ${ }^{2,3,4}$, K. E. Carpenter ${ }^{1}$, G. J. Edgar ${ }^{5,6,7}$, S. Henderson ${ }^{6}$, \\ J. Sanciangco ${ }^{1}$, D. R. Robertson ${ }^{8}$
}

${ }^{1}$ IUCN Species Programme Marine Biodiversity Unit, Biological Sciences, Old Dominion University, Norfolk, Virginia 23529, USA ${ }^{2}$ NatureServe, Arlington, Virginia 22203, USA

${ }^{3}$ World Agroforestry Center (ICRAF), University of the Philippines Los Baños, Laguna 4031, Philippines

${ }^{4}$ School of Geography and Environmental Studies, University of Tasmania, Hobart, Tasmania 7001, Australia

${ }^{5}$ Institute for Marine and Antarctic Studies, University of Tasmania, GPO Box 252-49, Hobart, Tasmania 7001, Australia

${ }^{6}$ Conservation International, Arlington, Virginia 22202, USA

${ }^{7}$ Charles Darwin Foundation, Puerto Ayora, Santa Cruz, Galápagos, Ecuador

${ }^{8}$ Smithsonian Tropical Research Institute, Balboa, Panama

\begin{abstract}
Marine conservation activities around the globe are largely undertaken in the absence of comprehensive species-specific information. To address this gap, complete regional species assemblages of major marine taxa are being progressively assessed against the Categories and Criteria of the International Union for the Conservation of Nature (IUCN) Red List of Threatened Species. The present study is the first analysis of entire major components of the biota of a large marine biogeographic region conducted in the Tropical Eastern Pacific (TEP). It is based on recently completed IUCN Red List assessments for all known species of bony and cartilaginous shorefishes, corals, mangroves, and seagrasses in the TEP. Twelve percent of the $>1600$ species assessed are in threatened categories, indicative of elevated extinction risk. Spatial analysis of all assessed taxonomic groups, including previous IUCN Red List assessments for seabirds, marine mammals, and marine turtles, highlights specific geographical areas of elevated threatenedspecies richness. The distribution of threatened species in the TEP is primarily linked to areas with high rates of overfishing, habitat loss, and increasing El Niño-Southern Oscillation (ENSO) event impacts, as well as oceanic islands with high stochastic risk factors for endemic species. Species assigned to the highest threat categories have life history traits that likely decrease their resilience to various regional and site-specific threats. Comprehensive information in the form of IUCN Red List assessments combined with spatial analysis will greatly help to refine both site- and speciesspecific marine conservation priorities in the TEP.
\end{abstract}

KEY WORDS: IUCN Red List · Tropical Eastern Pacific · Marine species · Extinction risk theory · Threatened species

Resale or republication not permitted without written consent of the publisher

\section{INTRODUCTION}

Information on the geographical and habitat distributions of threatened species is often used to refine marine conservation priorities, through the designation of critical habitat or key biodiversity areas, notake zones, and marine protected areas (MPAs); or to support policies that regulate resource use (Rodrigues et al. 2006, Edgar et al. 2008a, 2008b, Hoffmann et al. 2008). However, marine conservation priorities have often been identified and acted on in the absence of comprehensive species-level information (Margules \& Pressey 2000), as such data often do not exist or are difficult to collate. Among the $>50000$ 
species assessed over the past decade for the International Union for the Conservation of Nature (IUCN) Red List of Threatened Species (IUCN 2011a), only $\sim 3 \% \quad(<1500$ species) are marine. These species mainly comprise seabirds, marine mammals, marine turtles, and a few select fishes. To address this assessment gap, >20000 marine species, including all marine fishes and primary habitat producers such as reef-building corals, seagrasses, and mangroves, are currently in the process of assessment using the IUCN (2001) Red List Categories and Criteria through the Global Marine Species Assessment (www.sci.odu.edu/gmsa/).

Recent marine species extinctions, although fewer than those documented for terrestrial species (Briggs 2011), currently include at least 20 global species (Dulvy et al. 2009) and >133 local populations (Dulvy et al. 2003). The most recent probable global extinction, where good pre- and post-extinction data exist, is considered to have occurred in the Tropical Eastern Pacific (TEP), with the disappearance during the 1982-83 El Niño-Southern Oscillation (ENSO) event of the endemic Galapagos damselfish Azurina eupalama (Dulvy et al. 2009, Edgar et al. 2011). Drastic recent declines have also been documented across several marine groups, including many populations of commercial marine fishes (Hutchings \& Reynolds 2004, Worm et al. 2009), coral reef fishes (Wilson et al. 2006, Paddack et al. 2009), reef-building oysters (Beck et al. 2011), corals (Gardner et al. 2003, Pandolfi et al. 2003, Bruno \& Selig 2007), and seagrasses (Waycott et al. 2009).

In light of these documented declines, and as more pressure is put on marine resources from overfishing, habitat loss, pollution, and invasive species (Halpern et al. 2008, Worm et al. 2009, Mora et al. 2011), an increasing need exists to identify marine species that are at highest risk of extinction (Dulvy et al. 2004, Graham et al. 2011) and how they are distributed in different regions. Additionally, understanding differential species vulnerability to major threats is needed for determining how species communities and ecosystems are likely to respond to one or more concurrent stressors (Vinebrooke et al. 2004).

Several studies have been conducted to determine the relative extinction risk for marine fishes based on combinations of life history and ecological traits, habitat specialization, or body size and age at maturation (Munday 2004, Cheung et al. 2005, Reynolds et al. 2005a, Graham et al. 2011). Relative extinction risk has also been estimated for coral species based on bleaching response and abundance (McClanahan et al. 2007). However, application of these alternative techniques to assess extinction risk across multiple taxonomic clades is problematic due to the extreme variation in physiologies and life histories, and is therefore inefficient for prioritizing multi-taxa marine conservation targets.

The Categories and Criteria of the IUCN Red List (IUCN 2001) comprise the most widely accepted, standardized, quantitative system for classifying extinction risk at the species level (Butchart et al. 2005, De Grammont \& Cuarón 2006, Rodrigues et al. 2006, Hoffmann et al. 2008). These criteria have been applied to an increasingly wide variety of terrestrial, freshwater, and marine species, including all the world's mammals (Schipper et al. 2008), amphibians (Stuart et al. 2004), birds (BirdLife International 2008), reef-building corals (Carpenter et al. 2008), mangroves (Polidoro et al. 2010), seagrasses (Short et al. 2011), tunas and billfishes (Collette et al. 2011), groupers (Sadovy de Mitcheson et al. in press), and a number of other vertebrate, invertebrate, and plant clades (Hilton-Taylor et al. 2009). IUCN Red List Criteria are based on extinction risk theory (Mace et al. 2008) and provide quantitative thresholds to rank a species' relative probability of extinction. In general, extinction risk increases with small population sizes or distributional ranges, high rates of decline (e.g. death rates are greater than birth rates), and large fluctuations in population size relative to growth rates (Mace et al. 2008). Some criteria are most relevant for species with small population sizes, which have inherently high extinction risk due to stochastic events and genetic effects. Others are more appropriate for species with large population sizes that are experiencing high rates of decline or large fluctuations. These require extinction risk to be defined by measures of the species' ability to recover relative to the persistence and frequency of the stressors driving the declines and fluctuations.

Critics of the IUCN Red List have questioned whether criteria that are used to assess terrestrial animals, plants, and freshwater fishes should be the same as for marine fishes (Musick 1999, Powles et al. 2000). However, a number of empirical analyses suggest that the extinction probabilities of marine fishes are unlikely to differ substantially from those of other taxa (Hutchings 2000, 2001a, 2001b, Sadovy 2001, Dulvy et al. 2003). Thus, questions related to how adequately thresholds for rates of decline used in the Red List Criteria to assign species to IUCN categories actually reflect the likelihood that a particular population or species will become extinct is better asked of all taxa rather than only of marine species (Hutchings \& Reynolds 2004). 
Additionally, rather than focusing simply on marine versus terrestrial, specific taxonomic analyses arguably provide more meaningful comparisons. For example, among the world's plants, approx. $16 \%$ of mangroves (Polidoro et al. 2010) and 14\% of seagrasses (Short et al. 2011) are in threatened categories compared to approx. $35 \%$ of gymnosperms (HiltonTaylor et al. 2009), the only complete clade of terrestrial plants assessed to date. Among mammals, approx. $36 \%$ of marine mammals are considered to be at elevated extinction risk compared to $25 \%$ of terrestrial mammals (Schipper et al. 2008). Of the approx. 10000 marine and freshwater fishes assessed to date, approx. $30 \%$ of freshwater fishes and $15 \%$ of marine fishes are in threatened categories (IUCN 2011a). Among commercial fishes assessed to date, $11 \%$ of all tunas and billfishes are in threatened categories (Collette et al. 2011) as are $12 \%$ of the world's groupers (Sadovy de Mitcheson et al. in press). Successful assessment of each species group or clade through the Red List process often requires the development of unique definitions and interpretations in order to appropriately apply the IUCN Red List Criteria (Mace et al. 2008). Consequently, many of these relevant definitions and interpretations have been published for many taxa as they are globally assessed (e.g. Carpenter et al. 2008, Dulvy et al. 2008, Schipper et al. 2008, Polidoro et al. 2010, Collette et al. 2011, Short et al. 2011, Sadovy de Mitcheson et al. in press).

The present study is the first comprehensive Red List analysis conducted at the scale of a major marine biogeographic region, and it was performed with the marine fauna of the TEP. The TEP extends from southern Baja California through the Gulf of California and south to Peru, and includes 5 oceanic islands and archipelagos: the Revillagigedo Islands, Clipperton, Cocos, the Galapagos, and Malpelo islands (Robertson \& Cramer 2009). The TEP is a unique and dynamic region separated from adjacent tropical marine regions by the Central American isthmus on the east, and the world's broadest deep water barrier (4000 to $5000 \mathrm{~km}$ wide) on the west. The region has a small continental shelf, is more strongly affected by the ENSO-driven temperature changes than any other tropical region, and has an abundance of large, seasonal coastal upwellings, a shallow thermocline $(\sim 50 \mathrm{~m})$, relatively low salinity, and geographically highly variable rainfall (e.g. Glynn \& Ault 2000).

In the TEP, 1342 new IUCN Red List assessments conducted between 2005 and 2009 are now available, comprising all known species of bony and cartilaginous shorefishes, reef-building corals, mangroves, and seagrasses. In addition, the 74 species of Galapagos- endemic macroalgae have also been assessed. However, those results are not extensively discussed here because assessment is still needed for $\sim 400$ remaining macroalgal species that occur more widely through the TEP. Before these new data were available, IUCN Red List assessments were only available for 226 TEP species, mainly comprising seabirds, marine mammals, and marine turtles.

\section{MATERIALS AND METHODS}

Based on IUCN Red List methodology (IUCN 2001), species assessments were conducted from extensive input and collaboration with international and regional scientific experts, including members of the IUCN Species Survival Commission's Specialist Groups (IUCN 2011b). Data compilation and assessments were conducted in 9 taxonomically themed Red List assessment workshops held between 2005 and 2008 with the participation of $>200$ scientific experts. These covered all species known in each taxonomic group at the time. In each workshop, experts reviewed data on each species' taxonomy, distribution, population trends, ecology, life history, past and existing threats, and conservation actions to apply the IUCN Red List Criteria and assign each species a Red List Category. All species information and results of global Red List assessments are publicly available on the IUCN Red List of Threatened Species (IUCN 2011a). However, 85 of the non-endemic (e.g. circumtropical or Indo-Pacific) shorefishes have only been assessed regionally in the TEP. Although those results are included here, these TEP nonendemic assessments will not be published on the IUCN Red List until assessments of their global populations have been completed.

The IUCN Red List Categories comprise 8 levels of extinction risk: Extinct (EX), Extinct in the Wild (EW), Critically Endangered (CR), Endangered (EN), Vulnerable (VU), Near Threatened (NT), Least Concern (LC), and Data Deficient (DD). A species qualifies for 1 of the 3 'threatened' categories (CR, EN, or VU) by meeting the threshold for that category in 1 of 5 Criteria (A to E). These criteria form the real strength of the IUCN Red List as they are based on extinction risk theory (Mace et al. 2008) and provide a standardized methodology that can be applied consistently to any species from any taxonomic group such as tunas and billfishes (Collette et al. 2011), seagrasses (Short et al. 2011), mangroves (Polidoro et al. 2010), reef-building corals (Carpenter et al. 2008), mammals (Schipper et al. 2008), or amphibians (Stuart et al. 2004). 
For example, Criterion A measures extinction risk based on exceeding a threshold of population decline (30\% for VU, 50\% for EN, and $80 \%$ for CR) over a timeframe of 3 generations, a measure of reproductive turnover rate, in the recent past, and is generally applied to species with large or widespread populations. Criterion B measures extinction risk based on a small geographic range size (extent of occurrence $<20000 \mathrm{~km}^{2}$ or area of occupancy $<2000 \mathrm{~km}^{2}$ to meet the lowest threshold for VU) combined with continued decline and habitat fragmentation. Criterion $\mathrm{C}$ is applied to species with small population sizes estimated to be $<10000$ mature individuals, with continued decline. Criterion D is applied to species with $<1000$ mature individuals, or those with an area of occupancy of $<20 \mathrm{~km}^{2}$, or those that are found in $<5$ locations as defined by a threat. Criterion $\mathrm{E}$ is applied to species with extensive population information that allows for population declines to be appropriately modeled over time. Category NT is assigned to species that come close to but do not fully meet all the thresholds or conditions required for a threatened category under any of Criteria A to E, and Category LC is assigned if a species does not meet or come close to meeting any of the thresholds required of a threatened category.

All maps and related analyses, including number of species per country and endemism, were conducted in GIS, based on compiled species range maps. Original species range maps were obtained from a number of different sources (Spalding et al. 1997, Veron 2000, Green \& Short 2003, Jefferson et al. 2007, Ridgely et al. 2007, BirdLife International 2008, Robertson \& Allen 2008, SWOT 2009). All maps were reviewed and updated as necessary by IUCN Specialist Groups and at IUCN Red List Workshops. All species range maps used in our analyses were created based on polygons connecting known points of occurrence, with the exception of sea turtles, where only point locations of nesting sites were used.

To improve accuracy and to standardize analyses for near-shore species with relatively small ranges, a species polygon was cut to a $100 \mathrm{~km}$ shoreline buffer and maximum depth of $200 \mathrm{~m}$ if the species was found primarily above $200 \mathrm{~m}$ depth. This approach helped to improve the accuracy of analyses by standardizing species ranges and by excluding large areas of open ocean, where only pelagic larval stages of shallow-water demersal species may occur. For analyses of species richness, all species polygons were analyzed using a $10 \times 10 \mathrm{~km}$ square grid. This fine grid size was chosen to reduce over-estimation of ranges for small-range endemic species. Final maps were converted into a raster of $10 \times 10 \mathrm{~km}$ cell size to provide visualization of geographical biodiversity patterns.

\section{RESULTS AND DISCUSSION}

\section{Red List categorization}

Of the 1642 species in the TEP that have now been assessed for the IUCN Red List (see the supplement at www.int-res.com/articles/suppl/m448p093_supp. pdf), $12 \%$ (197 species) are in threatened categories (CR, EN, or VU). Marine turtles have the highest proportion of threatened species in the TEP (Fig. 1), with all 5 species present listed in 1 of the 3 threatened categories. Many of the habitat-producing groups also have a relatively high proportion of threatened species. Of these, $40 \%$ (4 of 10 species) of mangroves, $25 \%$ (1 in 4 species) of seagrasses, and $17 \%$ (8 of 46 species) of reef-building corals are in threatened categories, as well as $20 \%$ (15 of 74 species) of Galapagos-endemic macroalgae. Approx. 15\% (27 of 180 species) of cartilaginous fishes and $9 \%$ (94 of 1102 species) of the bony fishes in the TEP are now listed in a threatened category, as are approx. 15\% (9 of 62 species) of marine mammals and $21 \%$ (34 of 159 species) of seabirds.

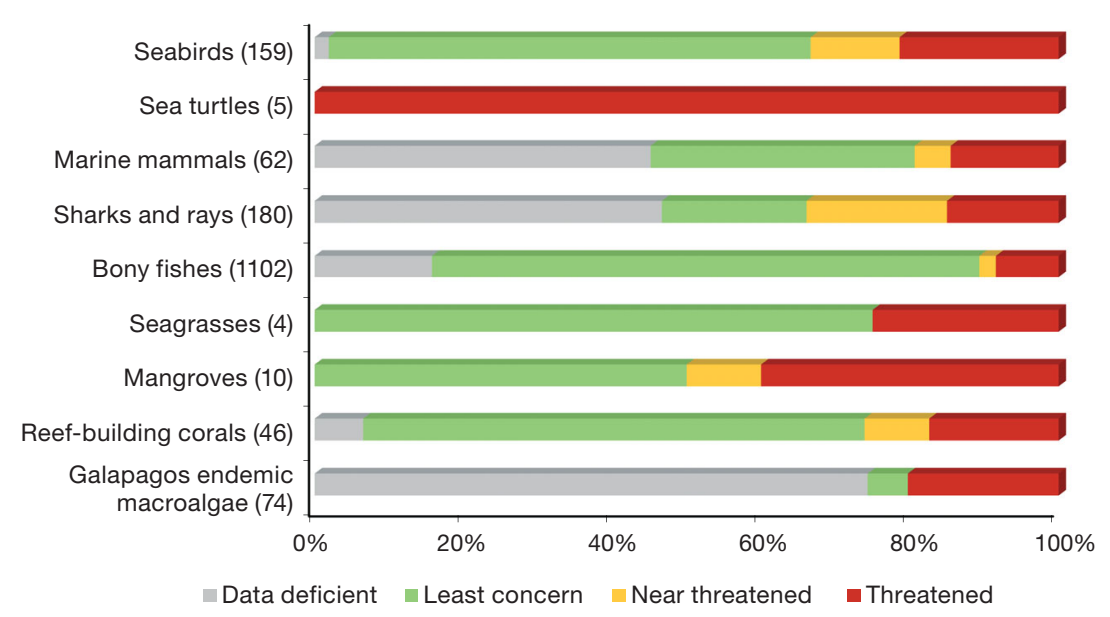

Fig. 1. Proportion of Tropical Eastern Pacific (TEP) species in IUCN Red List Categories for global assessments of major species groups. Numbers in parentheses refers to total number of species present in the TEP 


\section{Endemism}

The TEP has one of the highest rates of regional endemism of near-shore fishes of any tropical area of the world: almost $90 \%$ of bony fishes and $33 \%$ of cartilaginous fishes are endemic to the TEP (Robertson \& Cramer 2009). Further, $30 \%$ of mangrove species and $17 \%$ of reef-building coral species are endemic to the region (Glynn \& Ault 2000). With only approx. $25 \mathrm{~km}^{2}$ of structural coral reef in the TEP, mangroves - which are a major habitat feature on approx. onethird of the TEP coastline (Robertson \& Allen 2008) are by far the most dominant marine habitat-forming taxon.

Seabirds $(20 \%)$, marine mammals $(11 \%)$, and marine turtles $(0 \%)$ have relatively low regional endemism in the TEP. As the majority of species in these groups are widespread, pelagic, and/or highly migratory, areas of high threatened-species richness based on overlaps in the distributions of seabirds, marine mammals, and marine turtles primarily occur in the high seas and open ocean (Fig. 2A). The majority of globally threatened marine mammal species, for example, that occur in the TEP are found in temperate areas outside of the region (Schipper et al. 2008). Mar- ine mammal and marine turtle populations are affected by a number of different historical and current threats throughout their global oceanic range, including fishery by-catch, entanglement in fishing gear, boat strikes, noise pollution from military and seismic sonar, loss of prey or other food sources due to poor fisheries management, and historical or current effects of hunting (Reynolds et al. 2005b, Schipper et al. 2008, Polidoro et al. 2009, Wallace et al. 2010a). As these larger-scale threats may not all occur in the TEP region or may be difficult to mitigate on a local scale, mitigation of threats at the site or regional level for the majority of seabirds, marine mammals, and marine turtles may be limited to protection of known breeding or nesting sites (Wallace et al. 2010b).

\section{Spatial analyses}

Excluding Galapagos-endemic macroalgae, spatial analyses of the threatened marine species now known in the TEP (e.g. all marine mammals, marine turtles, seabirds, fishes, corals, mangroves, and seagrasses) highlight specific near-shore areas of high threatened-species richness (Fig. 2B) which are
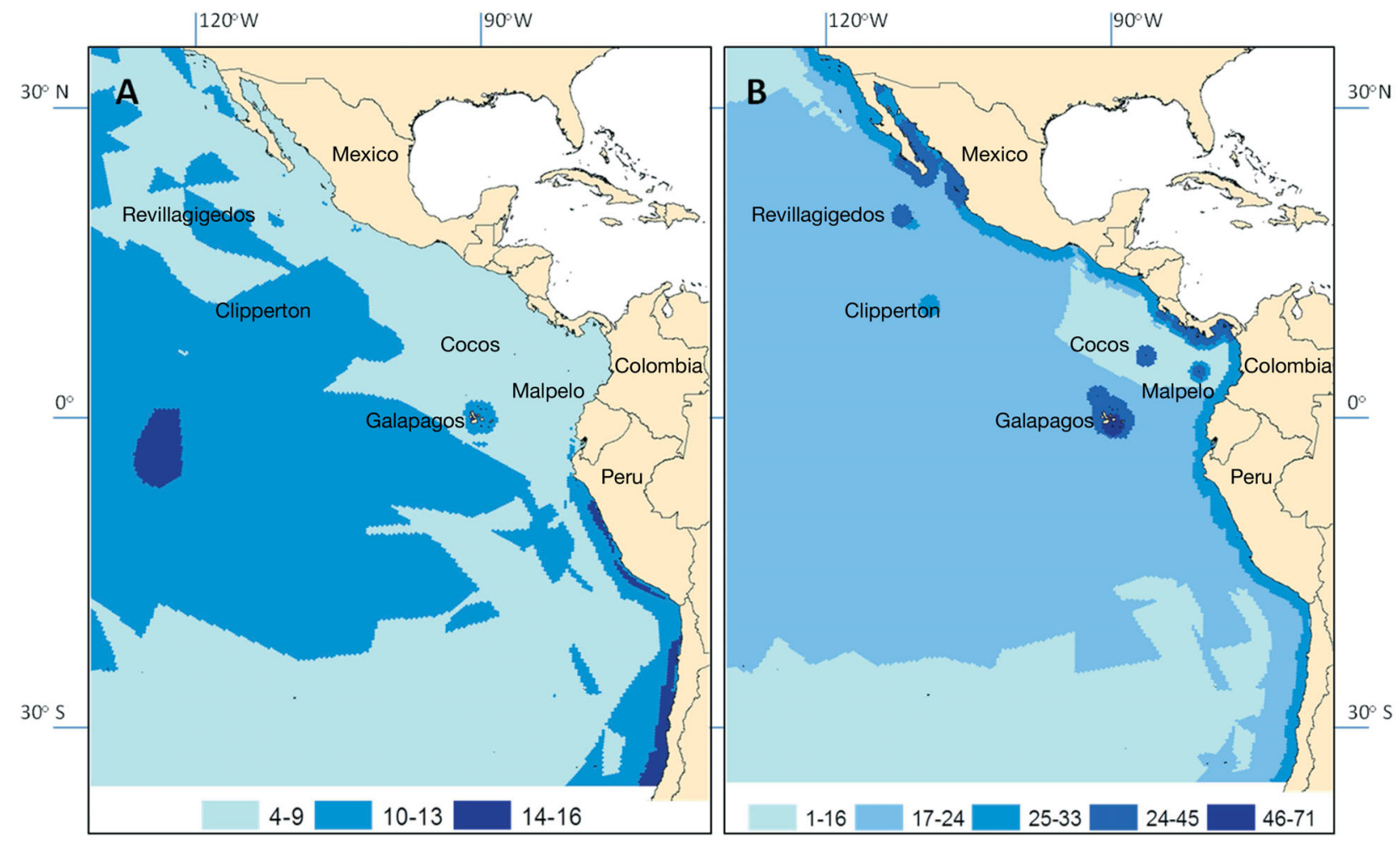

Fig. 2. Number of threatened species known in the Tropical Eastern Pacific (A) prior to 2008 (e.g. based on IUCN Red List Assessments for all seabirds, marine mammals, and marine turtles), and (B) as of 2010 (e.g. based on IUCN Red List Assessments for all seabirds, marine mammals, marine turtles, marine fishes, corals, mangroves, and seagrasses) 
related to different types of threats to species populations. High numbers of threatened species in the lower Gulf of California and along the Pacific coast of southern Baja, Mexico, are driven by species population declines due to overfishing and destructive fishing techniques, and the loss of critical habitat due to expansion of shrimp fisheries, coastal development, and diversion of virtually all the flow of the Colorado River for agriculture in the USA (Páez-Osuna et al. 1998, Lluch-Cota et al. 2007). Mexico hosts the highest number of marine species assessed (1081) and the highest number of threatened species (82) in the TEP (Fig. 3).

Spatial analyses show overlaps among threatened shore fishes and primary habitat-producer species, such as in the mangrove ecosystems along the coast of Costa Rica and Panama. Four of the 10 mangrove species present in the TEP are threatened, primarily due to intensive coastal development and extraction (Jiménez 1994, Polidoro et al. 2010). The Costa Rican and Panamanian coasts show high threatened-species richness (Fig. 2B), likely because this area has the highest abundance of species in the TEP (Robertson \& Cramer 2009). Among the 800 bony fishes that occur along this coastline, $>100$ are associated with mangrove habitat for at least a portion of their life stage (Robertson \& Allen 2008). Four mangrove-associated bony fishes are in threatened categories. Two gobioids (Gobulus birdsongi, Gobiosoma homochroma) and one clingfish (Tomicodon abuelorum) are only known from a few mangrove areas, and are threatened by continued coastal development, pollution, and removal of mangrove habitat. The sea catfish Notarius cookei, listed as Category VU, is known from $<5$ estuarine and mangrove areas in Panama

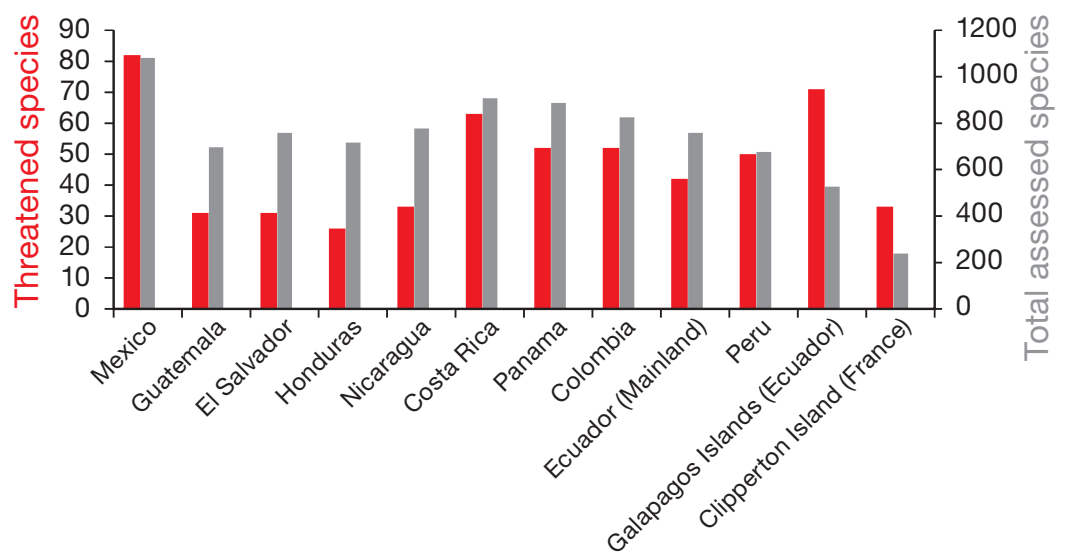

Fig. 3. Number of threatened species (red bar) and total number of species assessed (gray bar) within each country's Exclusive Economic Zone in the Tropical Eastern Pacific and is exposed to severe threats from river and coastal pollution as well as indiscriminate gillnetting in rivers.

The offshore islands of Revillagigedo, Clipperton, Cocos, Malpelo, and the Galapagos have high numbers of threatened species as a result of their numerous island-endemic species with very restricted ranges (Robertson \& Cramer 2009) that are affected by a combination of both anthropogenic and climateinduced threats. Approx. $14 \%$ of species assessed from Clipperton (33 of 239 species), the Revillagigedos (51 of 377 species), and the Galapagos archipelago (71 of 527 species) are in threatened categories (Fig. 3), as are approx. 12\% from Malpelo (41 of 341 species), and $11 \%$ from Cocos (46 of 405 species).

Clipperton is the only coral atoll in the TEP, contains the largest coral reef in the region, and is the only TEP location where all shallow habitat is produced by corals. The high proportion of threatened species, a very small area of shallow shoreline habitat $\left(\sim 4 \mathrm{~km}^{2}\right)$, and current lack of MPAs make the marine fauna of this tiny island uniquely vulnerable. This atoll is administered by the French Polynesian government in Tahiti, which only supports occasional, brief visits by its personnel, effectively eliminating any management or protection capacity. In contrast, all the other offshore islands in the TEP are entirely within MPAs. The Galapagos archipelago, which is surrounded by an MPA for a distance of 40 nautical miles offshore, has the second highest number of threatened species in the TEP after Mexico, and provides $95 \%$ of the insular shelf habitat in the TEP. Of the 71 threatened species that occur in the Galapagos, approx. half (34 species) are bony fishes with small geographic ranges that are threatened by overfishing or major oceanographic environmental changes arising from the increasing frequency, intensity, and duration of El Niño events (Grove 1985, Glynn 2000, Glynn \& Ault 2000, Chen et al. 2004, Edgar et al. 2010). The proportional abundance of threatened species off the coast of the 10 countries with continental shoreline are lower than those surrounding the oceanic islands of the TEP, ranging from 4 to $8 \%$. These differences illustrate the vulnerability of island marine faunas. Studies are currently underway to identify fine-scale sites of global biodiversity conservation significance in the Galapagos and TEP (Edgar et al. 2008a,b). 


\section{Critically Endangered species}

Species assigned to the highest threat categories have particular biological or ecological traits that provide poor adaptation to regional or site-specific threats. Four seabirds endemic to the TEP are listed as $C R$, the IUCN's highest threat category, 3 of which were assessed under either Criterion B or D due to their very restricted breeding areas and associated population declines caused by predation of nests or by incidental capture in fisheries (IUCN 2011a): Guadalupe storm-petrel Oceanodroma macrodactyla (possibly already extinct), waved albatross Phoebastria irrorata, and Townsend's shearwater Puffinus auricularis. Galapagos petrel Pterodroma phaeopygia, assessed as Category CR under Criterion A, has undergone extreme declines over the past $60 \mathrm{yr}$ primarily due to heavy predation of nests by introduced cats, dogs, and pigs (IUCN 2011a). The vaquita dolphin Phocoena sinus is the only Category CR marine mammal in the TEP. Assessed under both Criteria A and $\mathrm{C}$, this species has a total global population estimated to be $<250$ mature individuals, with catastrophic population decline primarily attributed to excessive incidental capture in gillnets in the northern Gulf of California (Rojas-Bracho et al. 2006).

Two marine turtles present in the TEP, the leatherback Dermochelys coriacea and the hawksbill Eretmochelys imbricata, have been globally assessed under Criterion A as Category CR. These long-lived species have experienced significant population declines in the past due to multiple threats to all stages of their life cycles, including loss of critical coastal nesting habitat, egg predation, targeted capture in small-scale subsistence fisheries, and by-catch (largely by long line and trawling activities). Both of these species have several significant sites for nesting along the mainland coast of the TEP.

Six endemic bony fishes in the TEP are listed as Category CR. Four of these species were assessed under Criterion $\mathrm{B}$, as they have very small distributions and are declining due to extensive habitat loss from coastal development and pollution (Paraclinus walkeri in Mexico, Gobulus birdsongi in Panama, Sciaena callaensis in Peru), or due to oceanographic environmental changes associated with increased ENSO cycle activity (Azurina eupalama in the Galapagos, listed as Category CR but quite possibly Category EX). Two other Category-CR endemic bony fishes found primarily in Mexico were assessed under Criterion A: Totoaba macdonaldi, which is endemic to the Gulf of California, and Stereolepis gigas, which also occurs in California. Both species have limited ability to cope with severe overfishing because they are large desirable food fishes, are relatively long-lived, and have spawning aggregations that are targeted by fishers (Barrera Guevara 1990). The T. macdonaldi population has also apparently been catastrophically affected by loss of spawning grounds dependent on flow from the Colorado River (Rowell et al. 2008). Rapid declines of the 2 Category-CR coral species (Millepora boschmai and Siderastrea glynni) in the TEP assessed under Criterion B have been linked to low resilience to ENSO-induced bleaching and disease following extensive coastal development, coral extraction, and pollution within their restricted ranges in Panama (Glynn \& De Weerdt 1991, Fenner 2001, Maté 2003).

\section{Data Deficient species}

Species assigned to the DD category may also be of conservation concern, and should be a priority for further research. A species is listed as DD if there are insufficient data to apply the Red List Criteria. This can apply to species that need taxonomic clarification, or that are only known from a few specimens. In some cases, relatively well-known species are listed as DD when significant threats are known but cannot be adequately quantified. Almost $75 \%$ of Galapagosendemic macroalgae are listed as $\mathrm{DD}$, primarily because many species have not been well studied and are only known from a few sites or are difficult to identify. As a result, little is known on their population size or trends, or on the impact of potential threats such as habitat warming from increased ENSO events. Approx. $45 \%$ of marine mammals and cartilaginous fishes in the TEP have been categorized as DD, primarily due to a lack of life history or population information needed to quantify the impact of known threats to these species. Many of those species spend long periods of time offshore and/or are highly migratory, which makes it difficult to conduct studies on population status or reproductive biology. Almost half of the $16 \%$ of bony fishes that are categorized as DD are heavily fished but lack reliable catch statistics and demographic information. Some of these commercial fishes likely will qualify in the future for a threatened category as better data on species biology, the history of fisheries landings or stock biomass, and catch per unit effort (CPUE) become available.

Of particular concern among the bony fishes is the Pacific goliath grouper Epinephelus quinquefasciatus. This TEP-endemic species was recently con- 
firmed as being distinct from its trans-Atlantic sibling species E. itajara (Craig et al. 2009). E. itajara has been listed as Category CR since 1996 due to overfishing. Although west Atlantic populations are showing some signs of recovery, notably in the southern USA due to a moratorium on fishing proposed in 1990, a listing of CR has been maintained until this species can be reassessed (likely in the next 5 yr). As catch landings data across the TEP for groupers are often lumped into a single category, there are very few species-specific data on population trends for E. quinquefasciatus. However, severe population reductions are suspected due to intensive fishing over the past 3 decades. Sala et al. (2004) found an increase in catch and CPUE for this species in the Gulf of California between 1960 and 1980, followed by a rapid decline, with both landings and CPUE close to zero since the $1990 \mathrm{~s}$. There is no reason to suspect that the situation is different anywhere else in the TEP, as E. quinquefasciata is a large, commercially valuable food-fish that likely matures at a large size (E. itajara matures at $1 \mathrm{~m}$ length). A near absence of recent records indicates that the situation for the Pacific goliath grouper is probably considerably worse than for its sister species in the Caribbean, which has been provided relief through a long-standing fishing moratorium in a significant proportion of its range. At present E. quinquefasciata is listed as DD, and better information on its population status, including landings, catch effort data, and biomass across its range in the TEP, are urgently needed.

\section{Major threats to species in threatened categories}

Oceanographic environmental changes, such as increased water temperatures and decreased productivity that are associated with an increasing duration and frequency of ENSO events in the TEP (Boer et al. 2004), is the major identified threat affecting the highest number of species listed in threatened categories across all taxonomic groups (Fig. 4). Almost 80\% (72 of 91 species) of bony fishes listed in threatened categories were considered to be negatively impacted by increasing ENSO events. All of these fishes are very small-ranging, primarily island endemics that are found in relatively shallow waters or within a narrow depth zone. Several marine mammals are also threatened by ENSO events, including Galapagos fur seals Arctocephalus galapagoensis (listed as Category EN), which have experienced declines from El Niñocaused ocean warming and up to $80 \%$ associated

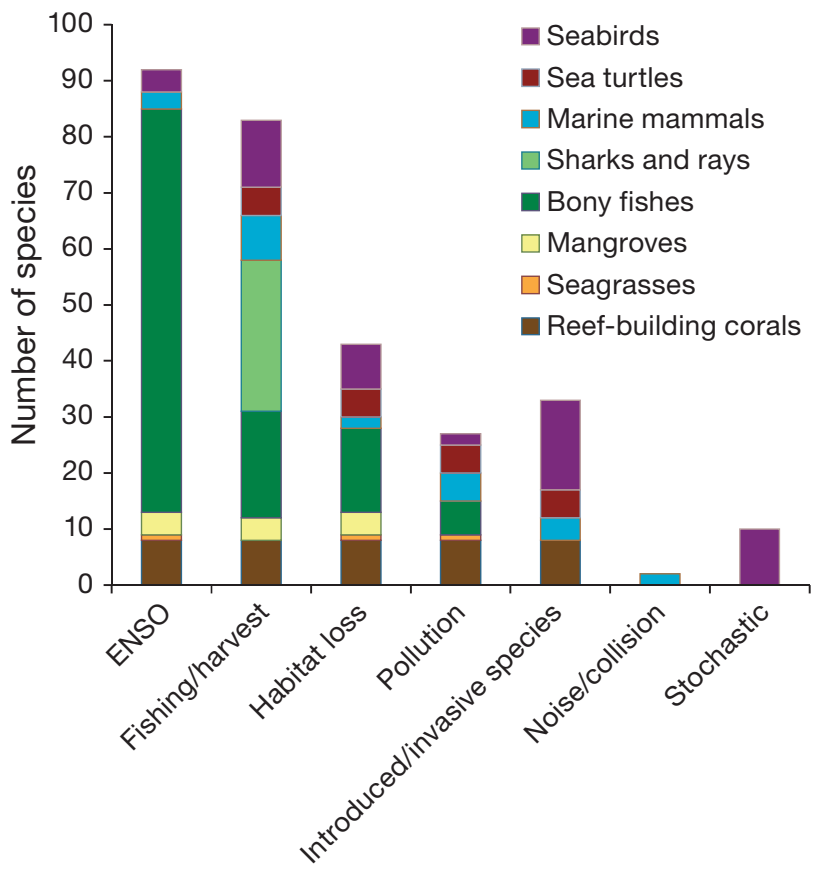

Fig. 4. Major threats impacting species listed in threatened categories in the Tropical Eastern Pacific. ENSO: El NiñoSouthern Oscillation

reduced marine productivity (Trillmich \& Dellinger 1991, Alava \& Salazar 2006). For similar reasons, the 1982-83 ENSO reduced the population of the Galapagos penguin Spheniscus mendiculus (also listed as Category EN) by $77 \%$, and the 1997-98 ENSO induced a further decline of $66 \%$ (Vargas et al. 2006). Increased coral bleaching and disease is also associated with ENSO events in the region (Glynn 2000), as is increased seagrass mortality (Orth et al. 2006) and loss of specific environmental conditions required for mangrove species (Ellison 2005).

In the TEP, large coastal populations and smallscale fisheries are dependent on marine species for food and income. Harvest or fishing, including capture as by-catch, is the second biggest threat in the TEP to the region's threatened species, although adequate data to quantify these effects on species' populations is largely absent. For example, capture as bycatch and targeted fishing for fins is the main threat to the region's threatened sharks and rays, yet almost half of all sharks and rays in the TEP are listed as DD because no information exists on the impact of direct or indirect fishing on these species.

Among the bony fishes, fishing and by-catch represents the largest threat in this region, with 19\% (207 of 1102 species) considered to be negatively impacted by targeted or incidental catch, even though related population declines were not always high 
enough to reach the threshold for a threatened category. In general, large-bodied marine fishes, such as the larger tunas and billfishes (Collette et al. 2011), attract high market prices and therefore tend to be under greater threat of global extinction due to commercial fishing (Olden et al. 2007). In addition to localized and regional depletion of some fishery species, there is regional evidence that overfishing of selected species has also led to harmful artificial imbalances in other fish and invertebrate communities (Edgar et al. 2011). Only $36 \%$ of bony fishes were considered to have no significant threats, and threats are suspected but undefined for $16 \%$ of bony fishes. Thus, estimates of the level of threat affecting regional shore fish fauna may well be underestimated.

Habitat loss, pollution, and predation or competition with introduced or invasive species are also significant threats to threatened species in the TEP. All species groups, with the exception of sharks and rays, are impacted by habitat loss in the region. Coastal development and near-shore alteration are the main factors contributing to habitat decline for many species in the TEP, including all of the region's threatened mangroves, seagrasses, and corals. Almost $10 \%$ of the region's bony fishes are impacted by habitat loss, primarily due to the removal or degradation of mangrove and estuarine habitats.

Ten species of threatened seabirds in the region have breeding populations so small that they are considered to be inherently threatened by probable stochastic events and human impacts, such as coastal development, habitat loss, predation, invasive species, tourism, or major storms. For example, the pinkfooted shearwater Puffinus creatopus (listed as Category VU) is found throughout the TEP, but only breeds on Robinson Crusoe Island and Santa Clara Island in the Juan Fernández Islands, and on Isla Mocha off the coast of Chile. It is estimated that there are $<20000$ breeding pairs of pink-footed shearwater (IUCN 2011a).

\section{Conservation and management}

Identification of threatened species and patterns of threat in the TEP can help guide local and regional marine conservation priorities for biodiversity conservation, as well as serve to inform policy. The presence of threatened species is used to identify marine key biodiversity areas and marine biodiversity hotspots, which target conservation action to areas where it is most needed and can have the most benefits in terms of species recovery (Roberts et al. 2002,
Edgar et al. 2008a). In the case of the TEP, important areas with high species richness and threatenedspecies richness include the Gulf of California, the coasts of Panama and Costa Rica, and the 5 offshore oceanic islands and archipelagos.

IUCN Red List species assessments can also be used to inform reserve system design and to constrain development and exploitation (Possingham et al. 2002). Tiny Clipperton Island has one of the highest proportions of threatened species in the TEP and a regionally unique habitat and faunal assemblage. The creation of a Clipperton MPA should be a high regional priority. Further, legislation to limit mangrove removal from important fishery nursing grounds along the coasts of Costa Rica and Panama is needed. For the few fishery species that are threatened based on the availability of adequate data, better management is needed on both local and regional scales. More importantly, however, increased reporting and better monitoring of by-catch are needed for the majority of species considered to be threatened by overexploitation in the TEP.

\section{CONCLUSIONS}

The availability of more comprehensive threatened species information is important for guiding marine conservation priorities, such as the improved management of MPAs, the development of more effective species conservation policies, or the identification of key biodiversity areas. Increased understanding of the factors that contribute to a species' threatened status is essential for developing the most effective measures to protect threatened species and to mitigate threats. Conservation action for threatened species will therefore be more effective in mitigating both species-specific and ecosystem wide threats if they are based on an understanding of the Red List Category, Criterion, and the specific threat or suite of threats under which a threatened species has been assessed.

Previously available Red List assessments of widespread and/or highly migratory species such as the majority of seabirds, marine mammals, and marine turtles could not be readily used to identify species or area-specific conservation priorities in the TEP, given that most threats to those species are global or historic (the exception being breeding sites; Bass et al. 2011). Analyses of the more comprehensive and recent species Red List assessments that include all marine fishes and primary habitat producers in the region, combined with an understanding of the crite- 
ria and data used to assess each species' probability of extinction, will more effectively identify areas of high threatened-species richness and patterns of threat for site- and species-specific marine conservation priorities. In terms of proportional abundance of threatened species, the highest threat levels exist for the ocean-island faunas. On the continental shore, the greatest abundances of threatened species occur around the mouth of the Gulf of California and the coastlines of Panama and Costa Rica. Those insular and continental areas represent priority conservation areas in the TEP. Regional scale conservation efforts exist, such as the Eastern Tropical Pacific Seascape Initiative (Shillinger 2005), that are making progress in addressing the range of threats to marine species. In several nations, including Mexico, Costa Rica, and Honduras, there are now total or seasonal closures for shark finning, although the level of enforcement is speculative. Regardless, better fisheries information and monitoring of by-catch should be an urgent priority for the improvement of marine conservation efforts throughout the region.

Acknowledgements. We thank Tom Haas and the New Hampshire Charitable Foundation and Conservation International's Eastern Tropical Pacific Seascapes Program for their generous support of the IUCN Red List and the Global Marine Species Assessment. We thank all of the scientists and partners involved in the Red List process for TEP species including the Charles Darwin Foundation, SeagrassNet, BirdLife International, University of Costa Rica, Smithsonian Tropical Research Institute, Roger McManus, and IUCN Species Specialist Groups (IUCN 2011b). Scientific contributors to all of the seabird, marine mammal, sea turtle, marine fishes, coral, mangrove, and seagrass species assessments are acknowledged under each species on the IUCN Red List of Threatened Species (www.iucnredlist.org). We also thank the following for their involvement in the TEP marine fish workshops: A. Acero, G. R. Allen, J. J. Alvarado, H. Araya, D. Barneche, P. Bearez, O. Bernal, S. Bessudo, R. Betancur, W. Bussing, M. Calvopina, N. L. Chao, B. Collette, M. Comeros Raynal, J. Cortes, A. Cotto, W. Crosse, E. Barraza, A. Dominici, W. Eschmeyer, H. Espinosa-Perez, L. Findley, M. Foster, N. Gaibor, R. Gonzalez, A. G. Guzman-Mora, I. Harrison, P. Hastings, M. Hoffmann, T. Iwamoto, B. Lea, S. R. Livingstone, M. Lopez, J. McCosker, E. Medina, G. Merlen, H. Molina, A. Mora, M. Mora, J. Nielsen, M. Quesada, F. Rivera, K. Rojas Jimenez, P. A. Rojas, E. Salas, L. Sierra, J. Smith, B. Smith-Vaniz, R. Toohey, L. Tornabene, J. Tyler, A. van der Heiden, J. van Tassell, R. Viquez, and F. Zapata.

\section{LITERATURE CITED}

Alava JJ, Salazar S (2006) Status and conservation of Otariids in Ecuador and the Galápagos Islands. In: Trites AW, Atkinson SK, DeMaster DP, Fritz LW, Gelatt TS, Rea LD, Wynne KM (eds) Sea lions of the world. Alaska Sea Grant College Program, Fairbanks, AK, p 495-520
Barrera Guevara JC (1990) The conservation of Totoaba macdonaldi (Gilbert), (Pisces: Sciaenidae), in the Gulf of California, Mexico. J Fish Biol 37:201-202

> Bass D, Anderson P, de Silva N (2011) Applying thresholds to identify key biodiversity areas for marine turtles in Melanesia. Anim Conserv 14:1-11

Beck MW, Brumbaugh RD, Airoldi L, Carranza A and others (2011) Oyster reefs at risk and recommendations for conservation, restoration and management. Bioscience 61: 107-116

BirdLife International (2008) State of the world's birds: indicators for our changing world. BirdLife International, Cambridge

Boer GJ, Yu B, Kim SJ, Flato GM (2004) Is there observational support for an El Niño-like pattern of future global warming? Geophys Res Lett 31:L06201, doi:10.1029/2003 GL018722

Briggs JC (2011) Marine extinctions and conservation. Mar Biol 158:485-488

Bruno JF, Selig ER (2007) Regional decline of coral cover in the Indo-Pacific: timing, extent, and subregional comparisons. PLoS ONE 2:e711

Butchart SHM, Stattersfield AJ, Baillie J, Bennun LA, Stuart SN (2005) Using Red List Indices to measure progress towards the 2010 target and beyond. Phil Trans R Soc B 360:255-268

- Carpenter KE, Abrar M, Aeby G, Aronson RB and others (2008) One-third of reef-building corals face elevated extinction risk from climate change and local impacts. Science 321:560-563

Chen D, Cane MA, Kaplan A, Zebiak SE, Huang D (2004) The predictability of ENSO over the last 148 years. Nature 428:733-736

Cheung WWL, Pitcher TJ, Pauly D (2005) A fuzzy logic expert system to estimate intrinsic extinction vulnerabilities of marine fishes to fishing. Biol Conserv 124:97-111

> Collette BB, Carpenter KE, Polidoro BA, Juan-Jorda MJ and others (2011) High value and long life-double jeopardy for tunas and billfishes. Science 333:291-292

> Craig MT, Graham RT, Torres RA, Hyde JR and others (2009) How many species of goliath grouper are there? Cryptic genetic divergence in a threatened marine fish and the resurrection of a geopolitical species. Endang Species Res 7:167-174

> De Grammont PC, Cuarón AD (2006) An evaluation of threatened species categorization systems used on the American continent. Conserv Biol 20:14-27

Dulvy NK, Sadovy Y, Reynolds JD (2003) Extinction vulnerability in marine populations. Fish Fish 4:25-64

Dulvy NK, Ellis JR, Goodwin NB, Grant A, Reynolds JD, Jennings S (2004) Methods of assessing extinction risk in marine fishes. Fish Fish 5:255-276

> Dulvy NK, Baum JK, Clarke S, Compagno LJV and others (2008) You can swim but you can't hide: the global status and conservation of oceanic pelagic sharks and rays. Aquat Conserv Mar Freshw Ecosyst 18:459-482

Dulvy NK, Pinnegar JK, Reynolds JD (2009) Holocene extinctions in the sea. In: Turvey ST (ed) Holocene extinctions. Oxford University Press, Oxford, p 129-150

> Edgar GJ, Langhammer PF, Allen G, Brooks TM and others (2008a) Key biodiversity areas as globally significant target sites for conservation of marine biological diversity. Aquat Conserv Mar Freshw Ecosyst 18:969-983

- Edgar GJ, Banks S, Bensted-Smith R, Calvopina M and others (2008b) Conservation of threatened species in the 
Galapagos Marine Reserve through identification and protection of marine Key Biodiversity Areas. Aquat Conserv Mar Freshw Ecosyst 18:955-968

Edgar GJ, Banks SA, Brandt M, Bustamante RH and others (2010) El Niño, grazers and fisheries interact to greatly elevate extinction risk for Galapagos marine species. Glob Change Biol 16:2876-2890

Edgar GJ, Banks SA, Bessudo S, Cortés J and others (2011) Variation in reef fish and invertebrate communities with level of protection from fishing across the Eastern Tropical Pacific seascape. Glob Ecol Biogeogr 20:730-743

Ellison J (2005) Holocene palynology and sea-level change in two estuaries in Southern Irian Jaya. Palaeogeogr Palaeoclimatol Palaeoecol 220:291-309

Fenner D (2001) Mass bleaching threatened two coral species with extinction. Reef Encounter 29:9-10

- Gardner TA, Cote IM, Gill JA, Grant A, Watkinson AR (2003) Long-term region-wide declines in Caribbean corals. Science 301:958-960

Glynn PW (2000) El Niño-Southern Oscillation mass mortalities of reef corals: a model of high temperature marine extinctions? In: Insalaco E, Skelton P, Palmer T (eds) Carbonate platform systems: components and interactions. Geol Soc Spec Publ 178:117-133

Glynn PW, Ault JS (2000) A biogeographic analysis and review of the far eastern Pacific coral reef region. Coral Reefs 19:1-23

Glynn PW, De Weerdt HW (1991) Elimination of two reefbuilding hydrocorals following the 1982-83 El Niño warming event. Science 253:69-71

Graham NAJ, Chabane P, Evans RD, Jennings S and others (2011) Extinction vulnerability of coral reef fishes. Ecol Lett 14:341-348

Green EP, Short FT (2003) World atlas of seagrasses. University of California Press, Berkeley, CA

Grove JS (1985) Influence of the 1982-1983 El Niño event upon the ichthyofauna of the Galápagos archipelago. In: Robinson G, del Pino EM (eds) El Niño in the Galapagos Islands: the 1982-1983 event. Charles Darwin Foundation for the Galapagos Islands, Quito, Ecuador, p 191-198

> Halpern BS, Walbridge S, Selkoe KA, Kappel CV and others (2008) A global map of human impact on marine ecosystems. Science 319:948-952

Hilton-Taylor C, Pollock CM, Chanson JS, Butchart SHM, Oldfield TEE, Katariya V (2009) State of the world's species. In: Vié J-C, Hilton-Taylor C, Stuart SN (eds) Wildlife in a changing world. Island Press, IUCN, Gland, p 15-42

> Hoffmann M, Brooks TM, da Fonseca GAB, Gascon C and others (2008) Conservation planning and the IUCN Red List. Endang Species Res 6:113-125

> Hutchings JA (2000) Collapse and recovery of marine fishes. Nature 406:882-885

> Hutchings JA (2001a) Influence of population decline, fishing, and spawner variability on the recovery of marine fishes. J Fish Biol 59(Suppl A):306-322

Hutchings JA (2001b) Conservation biology of marine fishes: perceptions and caveats regarding assignment of extinction risk. Can J Fish Aquat Sci 58:108-121

Hutchings JA, Reynolds JD (2004) Marine fish population collapses: consequences for recovery and extinction risk. Bioscience 54:297-309

IUCN (2001) IUCN Red List Categories and Criteria version 3.1. Available at www.iucnredlist.org/technical-documents/categories-and-criteria (accessed 1 Nov 2011)

IUCN (2011a) IUCN Red List of Threatened Species. Avail- able at www.iucnredlist.org (accessed 1 Nov 2011)

IUCN (2011b) Directory of SSC Specialist Groups. Available at www.iucn.org/about/work/programmes/species/about _ssc/specialist_groups/directory_specialist_groups/ (accessed 1 Nov 2011)

Jefferson TA, Webber MA, Pitman R (2007) Marine mammals of the world: a comprehensive guide to their identification. Academic Press, San Diego, CA

Jiménez JA (1994) El manejo de los manglares en el Pacifico de Centroamérica. Editorial Fundación UNA, Heredia, Costa Rica

> Lluch-Cota SE, Aragón-Noriega EA, Arreguín-Sánchez F, Aurioles-Gamboa D and others (2007) The Gulf of California: review of ecosystem status and sustainability challenges. Prog Oceanogr 73:1-26

Mace GM, Collar NJ, Gaston KJ, Hilton-Taylor C and others (2008) Quantification of extinction risk: the background to IUCN's system for classifying threatened species. Conserv Biol 22:1424-1442

Margules CR, Pressey RL (2000) Systematic conservation planning. Nature 405:243-253

Maté JL (2003) Corals and coral reefs of the Pacific coast of Panamá. In: Cortés J (ed) Latin American coral reefs. Elsevier Science, Amsterdam, p 387-417

McClanahan TR, Ateweberhan M, Graham NAJ, Wilson SK, Sebastian CR, Guillaume MMM, Bruggemann JH (2007) Western Indian Ocean coral communities: bleaching responses and susceptibility to extinction. Mar Ecol Prog Ser 337:1-13

> Mora C, Aburto-Oropeza O, Bocos AA, Ayote PM and others (2011) Global human footprint on the linkage between biodiversity and ecosystem functioning in reef fishes. PLoS Biol 9:e1000606

Munday PL (2004) Habitat loss, resource specialization and extinction on coral reefs. Glob Change Biol 10: 1642-1647

> Musick JA (1999) Criteria to define extinction risk in marine fishes. Fisheries (Bethesda, MD) 24:6-14

Olden JD, Hogan ZS, Vander Zanden MJ (2007) Small fish, big fish, red fish, blue fish: size-based extinction risk of the world's freshwater and marine fishes. Glob Ecol Biogeogr 16:694-701

> Orth RJ, Carruthers TJB, Dennison WC, Duarte C and others (2006) A global crisis for seagrass ecosystems. Bioscience 56:987-996

> Paddack MJ, Reynolds JD, Aguilar C, Appeldoorn RS and others (2009) Recent region-wide declines in Caribbean reef fish abundance. Curr Biol 19:590-595

Páez-Osuna F, Guerrero-Galván SR, Ruiz-Fernández AC (1998) The environmental impact of shrimp aquaculture and the costal pollution in Mexico. Mar Pollut Bull 36: 65-75

> Pandolfi JM, Bradbury RH, Sala E, Hughes TP and others (2003) Global trajectories of the long-term decline of coral reef ecosystems. Science 301:955-958

Polidoro BA, Livingstone SR, Carpenter KE, Hutchinson B and others (2009) Status of the world's marine species. In: Vié J-C, Hilton-Taylor C, Stuart SN (eds) Wildlife in a changing world. Island Press, IUCN, Gland, p 55-66

Polidoro BA, Carpenter KE, Collins L, Duke NC and others (2010) The loss of species: mangrove extinction risk and geographic areas of global concern. PLoS ONE 5:e10095

Possingham HP, Andelman SJ, Burgman MA, Medellin RA, Master LL, Keith DA (2002) Limits to the use of threatened species lists. Trends Ecol Evol 17:503-507 
Powles H, Bradford MJ, Bradford RG, Doubleday WG, Innes S, Levings CD (2000) Assessing and protecting endangered marine species. ICES J Mar Sci 57:669-676

Reynolds JD, Dulvy NK, Goodwin NB, Hutchings JA (2005a) Biology of extinction risk in marine fishes. Proc R Soc B Biol Sci 272:2337-2344

Reynolds JE, Perrin WF, Reeves RR (2005b) Marine mammal research: conservation beyond crisis. Johns Hopkins University Press, Baltimore, MD

Ridgely RS, Allnutt TF, Brooks T, McNicol DK, Mehlman DW, Young BE, Zook JR (2007) Digital distribution maps of the birds of the western hemisphere, version 3.0. NatureServe, Arlington, VA

Roberts CM, McClean CJ, Veron JEN, Hawkins JP and others (2002) Marine biodiversity hotspots and conservation priorities for tropical reefs. Science 295:1280-1284

Robertson DR, Allen GR (2008) Shorefishes of the Tropical Eastern Pacific: online information system, version 1.0. Smithsonian Tropical Research Institute, Balboa. Available at http://biogeodb.stri.si.edu/sftep/

Robertson DR, Cramer K (2009) Marine shore-fishes and biogeographic subdivisions of the Tropical Eastern Pacific. Mar Ecol Prog Ser 380:1-17

Rodrigues ASL, Pilgrim JD, Lamoreux JF, Hoffmann M, Brooks TM (2006) The value of the IUCN Red List for conservation. Trends Ecol Evol 21:71-76

Rojas-Bracho L, Reeves RR, Jaramillo-Legorreta A (2006) Conservation of the vaquita Phocoena sinus. Mammal Rev 36:179-216

Rowell K, Flessa KW, Dettman DL, Roman MJ, Gerber LR, Findley LT (2008) Diverting the Colorado River leads to a dramatic life history shift in an endangered marine fish. Biol Conserv 141:1138-1148

Sadovy Y (2001) The threat of fishing to highly fecund fishes. J Fish Biol 59(Suppl A):90-108

Sadovy de Mitcheson Y, Craig MT, Bertoncini AA, Cabanban A and others (in press) Fishing groupers toward extinction: a global assessment of threats and extinction risks in a billion dollar fishery. Fish Fish

Sala E, Aburto-Oropeza O, Paredes G, Thompson G (2004) Fishing down coastal food webs in the Gulf of California. Fisheries (Bethesda, MD) 29:19-25

Schipper J, Chanson JS, Chiozza F, Cox NA and others (2008) The status of the world's land and marine mammals: diversity, threat, and knowledge. Science 322: $225-230$

Shillinger GL (2005) The Eastern Tropical Pacific Seascape: an innovative model for transboundary marine conserva- tion. In: Mittermeier RA, Kormos CF, Mittermeier PRG, Sandwith T, Besancon C (eds) Transboundary conservation: a new vision for protected areas. Conservation International, Washington, DC, p 320-331

Short FT, Polidoro B, Livingstone SR, Carpenter KE and others (2011) Extinction risk assessment of the world's seagrass species. Biol Conserv 144:1961-1971

Spalding MD, Blasco F, Field CD (1997) World atlas of mangroves. International Society for Mangrove Ecosystems, Okinawa

Stuart SN, Chanson JS, Cox NA, Young BE, Rodrigues ASL, Fischman DL, Waller RW (2004) Status and trends of amphibian declines and extinctions worldwide. Science 306:1783-1786

SWOT (State of the World's Sea Turtles) (2009) State of the World's Sea Turtles nesting data interactive map. Available at http://seamap.env.duke.edu/swot (accessed 1 May 2009)

Trillmich F, Dellinger T (1991) The effects of El Niño on Galápagos pinnipeds. In: Trillmich F, Ono KA (eds) Pinnipeds and El Niño: responses to environmental stress. Springer Verlag, Heidelberg, p 66-74

> Vargas FH, Harrison S, Rea S, Macdonald DW (2006) Biological effects of El Niño on the Galápagos penguin. Biol Conserv 127:107-114

Veron JEN (2000) Corals of the world, Vol 1-3. Australian Institute of Marine Science (AIMS), Townsville

> Vinebrooke RD, Cottingham KL, Norberg J, Scheffer M, Dodson SI, Maberly SC, Sommer U (2004) Impacts of multiple stressors on biodiversity and ecosystem functioning: the role of species co-tolerance. Oikos 104:451-457

- Wallace BP, Lewison RL, McDonald SL, McDonald RK and others (2010a) Global patterns of marine turtle bycatch. Conserv Lett 3:131-142

> Wallace BP, DiMatteo AD, Hurley BJ, Finkbeiner EM and others (2010b) Regional management units for marine turtles: a novel framework for prioritizing conservation and research across multiple scales. PLoS ONE 5:e15465

Waycott M, Duarte CM, Carruthers TJB, Orth RJ and others (2009) Accelerating loss of seagrasses across the globe threatens coastal ecosystems. Proc Natl Acad Sci USA 106:12377-12381

Wilson SK, Graham NAJ, Pratchett MS, Jones GP, Polunin NVC (2006) Multiple disturbances and the global degadation of coral reefs: Are reef fishes at risk or resilient? Glob Change Biol 12:2220-2234

Worm B, Hilborn H, Baum JK, Branch TA and others (2009) Rebuilding global fisheries. Science 325:578-585

Submitted: June 6, 2011; Accepted: December 8, 2011

Proofs received from author(s): February 17, 2012
Editorial responsibility: John Choat,

Townsville, Queensland, Australia 